\title{
最近の歯学
}

\section{7. 咀 嚼}

\section{咀 嚼 運 動 と筋 紡 錘}

(咀嚼運動時length follow up servo controlは働いているか)

東京医科歯科大学顎口腔総合研究施設咀嚼研究部門 角 野 隆 二

咀嚼筋群のらち閉口筋である咬筋および側頭筋中には 多数の筋紡錘の存することは人間を含めて種々の動物で 証明されているが1,2)，正常咀嚼時これらの筋紡鍾がどの よらな㗢きをするかは今だに明らかにされていない。 1963年 Murphy ${ }^{3)}$ は length follow up servo control 説 ${ }^{4)}$ を咀嚼運動に適用して, 咀嚼筋の興奮は主に 介して行われ，急に食物がくだかれたとき閉口筋中の筋 紡鉠への負荷が一過性に減少し, GIa 群入力が減ずる, そ の結果, 閉口筋運動ニューロンを脱促進させ, 瞬間的に 閉口筋の収縮力を弱める。一方咀嚼中食物などにより急 に運動抵抗が増すと筋紡錘よりの入力が増大し, 閉口筋 が強く收縮するという咀嚼運動調節機構を仮定した。し かし, これはあくまでも仮説であり, 何らの実証はなか った。ところが最近無麻酔無拘束動物で閉口筫筋紡錘の 求心性活動を三叉神経中脳路核内で記録することが技術 的に可能になり, 随意顎運動と筋紡錘の活動との関係の 定量的解析がなされるようになって来た。Matsunami＆ Kubota $(1972)^{5)}$ はサルを用いて, 約半数の閉口筋筋紡 錘上りの求心性ニニットは閉口筋収縮時にその活動が増 大することにより，随意咀嚼運動時 $\alpha$-運動ニューロンと 同時に $\gamma$-運動ニューロンも活性化されている $(\alpha-\gamma$ coactivation）と結論 した。しかし彼らはまた閉口筋筋電 活動と筋紡錘ユニットの発射頻度の間に何らの関係を認 めないことより，まず筋紡錘が活性化され，これによって 次に $\alpha$-運動ニューロンが興奮させられるといら典型的 な lengthservo control を否定した。Goodwin \& Luschei (1975) もほぼ同じ結論を述べているが，乙かし彼らは筋 紡錘の求心性発射頻度が常に筋が伸展される開口時に最 高であることより受動的な伸展受容器 (stretch receltor) としての機能を強調した。更に彼らは両側性に三叉神経 中脳路核を破壊して下顎反射 (jaw-jerk) を消失せしめた 後も咀䀶運動の運動パターンや笳電活動のタイミングに 变化のないことを観察し正常咀嚼運動に閉口管筋紡錘入 力はあまり積極的に貢献していないのだろらと推察して
いる7)。Cody, Harrison \& Taylor (1975) はネコで咀嚼中 の最大頻度をもとにして筋紡錘求心ニニットを高頻度二 ニット $(240 \sim 600 \mathrm{imp} / \mathrm{s})$ と低頻度ニニット $(80 \sim 200 \mathrm{imp} /$ s) に分類し, 前者は筋の伸展速度をよく感受することに より一次終末 (primary ending) 後者は伸展の長さをよ く感受することにより二次終末（secondary ending）よ りのものであろらと推定した。彼らもまた低頻度二ニッ トに $\alpha-\gamma$ co-activation を認めているが, これは直接の運 動ニューロンを興奮さすといらより, 運動を正確に計測 するに適するようにその感受性を調節し, 筋紡錘を伸展 受容器 (strech receptor) として機能的に働かしているの だろらと推論している。すなわち動物実験では正常咀嚼 運動時 Merton のいら筋紡錘を介する length follow up servo control は行われていないと思われる。ところが最 近 Lumarre \& Lund $(1975)^{9)}$ は人間の随意閉口中急に筋 を伸展しない程度の負荷を与えると 5 〜 $10 \mathrm{msec}$ の潜時 で咬筋筋電活動が一過性に増強し, 閉口運動の速度を早 める, 反対に負荷を減ずると同じ潜時で筋電活動が抑圧 される負荷代償系 (load compensatin system) の存する ことを䜑め，その潜時が下顎反射 (jaw-jerk) の潜時とほ ぼ等しいこと, 筋紡錘を欠く開口筋顎二腹筋では短潜時 の負荷代償作用のないこと，また歯根膜を麻酔した後こ の作用のかえって増強されることなどより彼らはこの負 荷代償系は単シナプス性に閉口筋の筋紡錘を介して働い ているのだろらと示唆している。すると人間ではサルや ネコと違った顎運動調節機構が働いている可能性が考兄 られるが，現在までとれを積極的に支持する証拠は見つ かっていない。

\section{文 献}

1) Cooper, S.: Muscle spindles \& other muscle receptors. Bourne, G. M. (ed), The Structure and Function of Muscle. New York 1960, Academic Prens, pp. 381-420.

2) Kubota, K., Masegi, T. \& Sato, Y.: Propriocep- 
tive organ of the jaw muscles. Advance in Neurological Sciences (神経研究の進歩), 18: 30-40, 1974.

3) Murphy, T. R.: Shortening/inhibition of prime movers. A safty factor in mastication. Br. Dent J., 123: 578-584, 1967.

4) Merton, P.A.: Speculation on the servo control of movement. Wolstenholme, G. E. W. (ed) The Spinal Cord. London, 1953, Churchill, pp. 247-255.

5) Matsunami K. \& Kubota, K.: Muscle afferents of trigeminal mesencephalic tract nucleus and mastication in chronic monkeys. Jap. J. Physiol., 22: 545-555, 1972.

6) Goodwin G. M. \& Luschei, E. S.: Discharge of spindle afferernts for jaw-closing muscles during chewing in alert monkeys. J. Neurophysiol., 38: 560-571, 1975.

7) Goodwin, G. M. \& Luschei, E. S.: Effects of destroying spindle afferents from jaw-muscles on mastication in monkeys. J. Neurophysiol., 37: 967-981, 1974.

8) Cody, F. W. J., Harrison, L. M. \& Taylor, A.: Analysis of activity of muscles during normal movements in the cat. J. Physiol., 253: 565582, 1975.

9) Lamarre, Y. \& Lund, J. P.: Load compensation in human masseter muscles. J. Physiol., 253: 21-35, 1975. 